Article

\title{
Vindication of Linking Social Capital Capacity to Urban Agriculture: A Paradigm of Participation Based on Social Empowerment in Klang Valley, Malaysia
}

\author{
Nur Shuhamin Nazuri ${ }^{1}$, Mohd Roslan Rosnon ${ }^{1, *}$, Nobaya Ahmad ${ }^{1}$, Siti Shazwani Ahmad Suhaimi ${ }^{1}$ (D, \\ Juwaidah Sharifuddin ${ }^{2}$ and Rusitha Wijekoon ${ }^{1}$ (D)
}

check for updates

Citation: Nazuri, N.S.; Rosnon, M.R.; Ahmad, N.; Suhaimi, S.S.A.;

Sharifuddin, J.; Wijekoon, R. Vindication of Linking Social Capital Capacity to Urban Agriculture: A Paradigm of Participation Based on Social Empowerment in Klang Valley, Malaysia. Sustainability 2022, 14, 1509. https://doi.org/10.3390/su14031509 Academic Editors: Dalia Štreimikienè and Jana Šiftová

Received: 29 November 2021 Accepted: 28 December 2021 Published: 28 January 2022

Publisher's Note: MDPI stays neutral with regard to jurisdictional claims in published maps and institutional affiliations.

Copyright: (c) 2022 by the authors. Licensee MDPI, Basel, Switzerland. This article is an open access article distributed under the terms and conditions of the Creative Commons Attribution (CC BY) license (https:// creativecommons.org/licenses/by/ $4.0 /)$.
1 Faculty of Human Ecology, Universiti Putra Malaysia, Serdang 43400, Selangor, Malaysia; nurshuhamin@gmail.com (N.S.N.); nobaya@upm.edu.my (N.A.); shazwani.suhaimi87@gmail.com (S.S.A.S.); kuruppuwijekoon@gmail.com (R.W.)

2 Faculty of Agriculture, Universiti Putra Malaysia, Serdang 43400, Selangor, Malaysia; juwaidah@upm.edu.my * Correspondence: roslan_rosnon@upm.edu.my

\begin{abstract}
With the rise of urbanization, the Malaysian government faces a tough challenge in ensuring food and nutrition security, especially for the disadvantaged urban populations. Urban agriculture (UA) seems to be a feasible approach to be undertaken by the government to overcome urban food insecurity. In distinguishing UA as a vital element of sustainable urban development, the primary challenge is to develop effective programs that engage urban dwellers and organizations through good design and implementation. Additionally, empowering communities through UA programs is challenging. Hence, the major aim of this study is to ascertain the assigned and underlying values of UA participation amongst communities that contribute to aspects of community social empowerment in Klang Valley, Malaysia. The dataset for the study was taken from the respondents (180) who were the participants of UA community programs authorized by the Department of Agriculture in Klang Valley area, and a Structural Equation Modelling using Partial Least Square (PLS-SEM) was utilized to integrate the interdependencies between multiple variables. The findings revealed the important role of participation in the planning, implementation, and evaluation of UA programs to ensure success. Participation should be seen through the roles of agencies, NGOs, and communities in order to build a strong network crucial to the enhancement of social empowerment among participants of UA programs.
\end{abstract}

Keywords: evaluation; implementation; planning; social capital; social empowerment; urban agriculture; urbanization

\section{Introduction}

Urbanization, a process in which people migrate from rural to urban areas, has resulted in a decline of the rural population [1]. It is primarily the process by which cities expand in size as more people move into major areas to live and work. According to the FAO [2], two-thirds of the population in the world will be living in cities by 2050. The level of urbanization in Asia is now approximately 50\% [3]. Malaysia, one of the fast-developing countries in the Asia Pacific region, has also become one of the most urbanized developing countries. Therefore, it also faces grave issues relevant to urbanization. The urbanization rate has accelerated, and Malaysia has been listed as the third-highest country $(77.2 \%)$ with high urbanization rates in Southeast Asia from 2015 to 2020, as shown in Figure 1. 


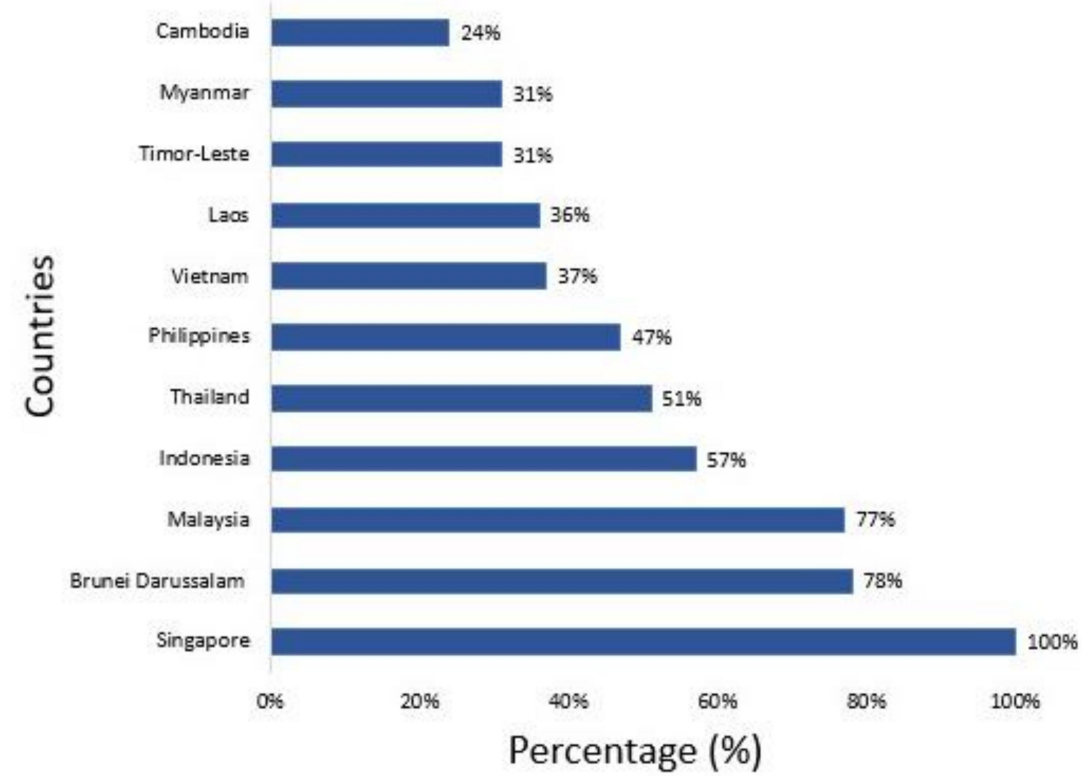

Figure 1. Percentage of population living in urban areas of South-East Asian countries, 2020; Cambodia-24\%, Myanmar-31\%, Timor-Leste-31\%, Laos-36\%, Vietnam-37\%, Philippines-47\%, Thailand-51\%, Indonesia—57\%, Malaysia—77\%, Brunei Darussalam-78\%, and Singapore-100\%. Source. World Urbanization Prospects (2020) [4].

According to the United Nations Department of Economic and Social Affairs (DESA), Malaysia was recorded in an urbanization rate of $80 \%$ in 2020 and $85-90 \%$ in the next 30 years [5]. Based on the Malaysia Household Income and Basic Amenities Survey Report [6], there is a $119.7 \%$ urbanized population growth in all states of Malaysia, with the Federal State of Kuala Lumpur (100\%), the Federal State of Putrajaya (100\%), Selangor (94.5\%), and Pulau Pinang (96.2\%) holding the highest rates of urbanization (see Figure 2). Thus, the migration of people from rural to urban regions has resulted in food insecurity, high costs of living, jobless citizens, and urban poverty [7]. With Malaysia's increasing urban population, there is growing concern about the cumulative impacts of land fragmentation, resource depletion, higher food costs, increased poverty, increasing unemployment, and urban environmental degradation. As the Malaysian government is committed to ensuring the population's quality of life and food security, concerted efforts have been made to implement the Urban Agriculture (UA) initiative in Malaysia.

In her past study, Lin et al., (2015) mentioned that numerous cities in developing countries are now encouraging UA in response to issues such as urbanization, food insecurity, and climate change [8]. UA encompasses activities related to agriculture and agricultural operations in urban areas, and it is a practice of cultivating fruits, grains, root crops, vegetables, herbs, and livestock, which has been practiced by 800 million people worldwide [9]. Production takes place in rooftops, backyards, community garden spaces, and unused or public places [2]. The benefits of UA are wide ranging, including improving food security [10]; generating income [11]; improving the quality of the urban environment toward sustainability [12]; and providing job opportunities. Participants involved in UA programs gain direct access to locally produced fresh foods that broaden food diversity while also offering employment opportunities and generating some income through the sale of surplus produce $[13,14]$. Recognition of the positive impacts from UA has led to the development of policies and initiatives that seek to encourage Malaysians to get involved in this activity. The government has established several initiatives and policies to promote the UA program. For instance, the National Agro-food Policy (NAFP) 2011-2020 plays a significant role in serving as a guideline for development of the agricultural sector in Malaysia [15]. The policy's objectives are to address domestic and global issues affecting food security in order to assure its sustainability by reforming and transforming the 
agro-food industry to become more dynamic and fit with urban requirements as enhanced using modern technologies that can be equipped in the limited space available for activities. Accordingly, the UA program has been put under the authority of the Department of Agriculture since 2010 with the name "Pertanian Bandar". The purpose of this program is to help urban communities reduce their cost of living through the production of their own food to meet their daily needs and as an additional income for urban communities through the sale of surplus produce [16].

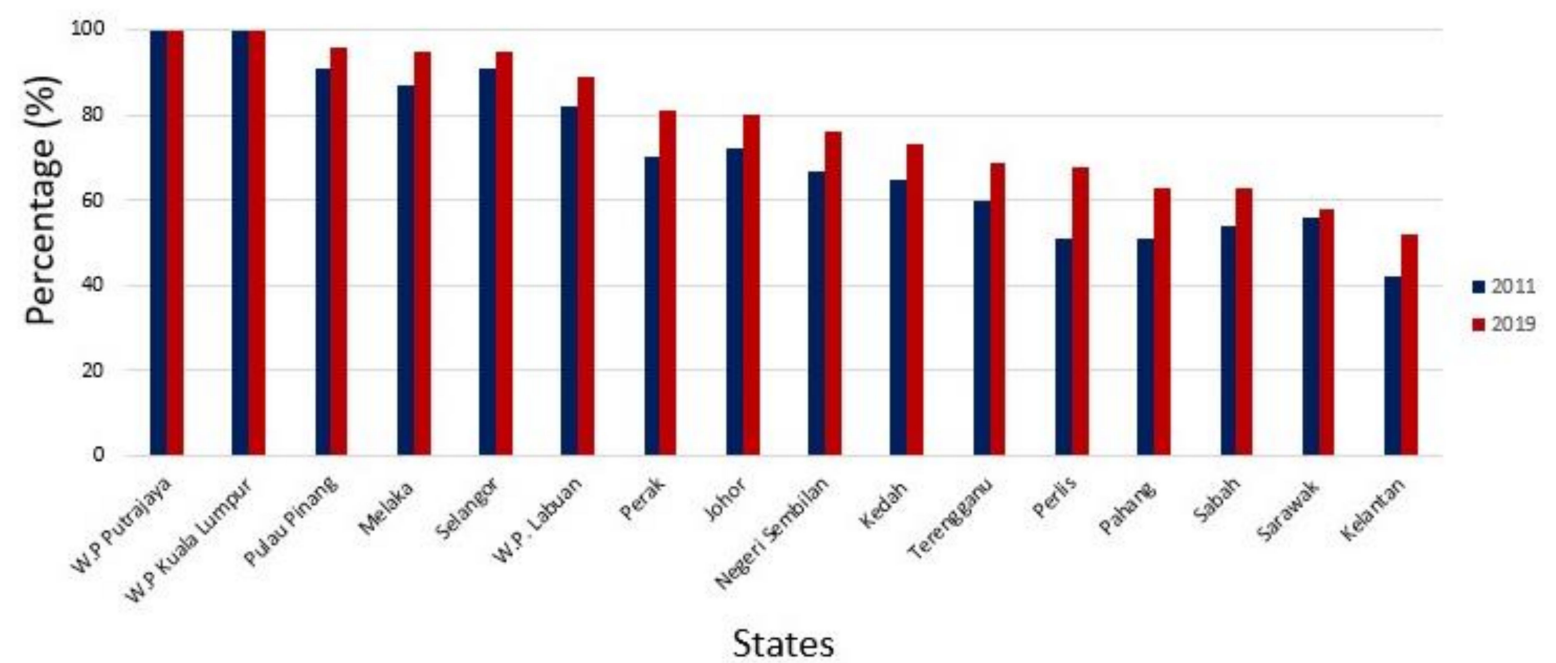

Figure 2. Level of urbanization by state, Malaysia, 2011 and 2019. Source. Department of Statistics Malaysia [6].

Sustainable Development Goals (SDGs) are a series of measures and goals aimed at eradicating poverty and ensuring the global well-being of human beings [17]. In line with the SDGs' main agenda, UA is seen as an advantageous program that contributes to sustainable urban development in terms of providing fresh food supply, especially for low-income families. The SDGs have highlighted the importance of agriculture in sustainable cities, specifically in Target 11, goal 3, which states the need to "make cities and human settlements inclusive, safe, resilient, and sustainable in order to ensure healthy lives and promote well-being for all ages". Thus, all countries should aim to work on enhancing the inclusivity and sustainability of urbanization in order to plan programs that are participatory, integrated, and sustainable for human settlement planning and management in all countries. However, despite the numerous recognized benefits of UA, there are still a number of obstacles preventing it from rapid take-up [8]. Although UA is no longer an alien term in Malaysia, the employment of UA as an approach to solving urban challenges has not yet received adequate attention as a solution for urban food scarcity. Despite the government's efforts, there exists a lack of community awareness and participation [18]. In order to achieve UA's full potential for social and economic profitability as well as ensure the sustainability of the program, implementation in UA must be participatory. This highlights the fact of why the program's success is highly contingent upon urban volunteers. Noriah Mat, Senior Deputy Director of Putrajaya Corporation's Landscape and Parks Development highlighted that community garden programs face a community outreach issue [19]. As a result, the Community Garden Program's sustainability has been cast into doubt [20]. To distinguish UA as a vital element of sustainable urban development, the primary challenge is to develop effective programs that engage urban dwellers and institutions in designing and implementing UA. Given the scarcity of research on this area of study, this project was undertaken to ascertain and comprehend the values that the community of Klang Valley imposes on UA in Malaysia. Therefore, the purpose of this study is to ascertain the assigned and underlying values 
of UA participation amongst communities that contribute to aspects of community social empowerment in the Klang Valley area of Malaysia.

Past studies have been using the term "empowerment" vaguely without overlooking the probability of additional variables that could enhance the potency of empowerment. There are scarce existing theories that deal independently with UA participants' empowerment. The theories and models have clarified factors that contribute to empowerment, and the researchers have come up with "participation" as being the main factor influencing empowerment [21,22]. To better comprehend its antecedents, the authors unified concepts and variables from dissimilar theoretical frameworks in order to demonstrate that the UA participants' empowerment has resulted from participation in three dimensions: namely, planning, implementation, and evaluation. Participation is an integral element of social change effort and improvement [23]. Participation can assist and empower participants and teach them valuable decision making, communication, and research skills while transitioning the program's structure from a top-down to a collaborative service model [24]. Previous studies have also mentioned that participation is a medium for empowerment to take place-when people are in a group that is engaged in identifying problems, decision making, and implementing a program, they learn together, develop their confidence and skills, and subsequently contribute to their own development. This notion has been used in many studies related to community programs such as women programs [25], youth programs [26], and health programs [27].

\section{Material and Methods}

\subsection{Hypotheses Development}

\subsubsection{Participatory Planning}

Planning is the first method in the participatory approach, and it acts as the stage where a strategy is developed in order to accomplish the objective of a program. The successful completion of a program requires careful planning. Planners should examine the program's execution, timeline, duration, and size of the targeted group when in the planning stage [28]. Participatory strategic planning brings participants to the center of the planning process and helps to empower the participants socially by teaching them valuable decision making, research, communication, and other skills while altering the structure from a top-down service model to a cooperative service approach [29]. UA is typically viewed as a strategy to achieve larger social or economic goals within the comprehensive planning process [30]. A study done by Thibert (2012) found that to perform sustainable UA in the United States, communities require rigorous planning along with good support and adequate resources in order to be successful [31]. As summarized by Horst et al., (2017), planning can play a stronger role in the movement for food justice, increased food security, reduced social inequality, and increased communities' quality of life [32]. Hence, it is expected that a specific planning process will lead to higher participants' social empowerment. Accordingly, the following hypothesis was suggested;

Hypothesis 1 (H1). Participatory planning positively and significantly affects social empowerment.

\subsubsection{Participatory Implementation}

Studies have shown that program implementation influences participants' social empowerment. The findings of a study conducted by Gagnon et al., (2015) suggested that implementation is a critical aspect of the planning and development of US cooperative extension programs and services [33]. If the importance of implementation is clear, programs conveyed with high-quality implementation tend to yield positive outcomes to the participants more consistently than programs delivered with lower-quality implementation [34]. Community members are also often included in discussions on the obstacles faced during UA implementation, which is a process that brings benefits to them in return. In view of this, we proposed to test the following hypothesis: 
Hypothesis 2 (H2). Participatory implementation positively and significantly affects social empowerment.

\subsubsection{Participatory Evaluation}

Participation in the evaluation process has been found to influence social empowerment. For example, Hoe et al., (2017) reported that participation of the urban community in program evaluation encouraged more people in the longhouses to join in, whether direct or indirect, in the implementation of development programs [35]. For the UA program, Prasetyo al. (2020) stated that evaluation acts as a baseline to determine the next step to be done, what needs to be improved, and what needs to be maintained to sustain the UA program [36]. On the other hand, Weaver and Cousins (2004) classified participatory evaluation into "practical participatory evaluation, which is more utilization-oriented and mainly focused on local problem solving, and transformative participatory evaluation, which is more emancipatory, with a strong empowerment component" ([37], p. 23). In view of this, it is expected that participatory evaluation will lead to the social empowerment of the UA program's participants. Accordingly, the following hypothesis was proposed:

Hypothesis 3 (H3). Participatory evaluation positively and significantly affects social empowerment.

\subsubsection{Moderation Effect of Social Capital Linking}

The relationship between social capital links and empowerment has been established in the literature $[38,39]$. The linking of social capital has mobilized communities to be self-reliant. It assists communities in discovering their own potential and relying on their own resources. The act of linking social capital refers to "norms of respect and networks of trusting relationships between people who are interacting across explicit, formal, or institutionalized power or authority gradients in society" ([40], p. 3). Social capital linking connects individuals and communities to agents with noteworthy resources or power [41]. Woolcock (2002) highlighted that "the key function of linking social capital is the capacity to leverage resources, information, and ideas from formal institutions" ([42], p. 23). Bakker et al., (2019) showed that social capital links play a significant role in community facilitation [43]. Social capital linking has also been identified as particularly important for community well-being [41].

While the direct impact of the previously identified predictors on empowerment may exist, the community's social capital can both encourage and discourage UA. The extent to which participation elements influence empowerment is contingent upon how a community engages in UA. Additionally, the study predictors appear to moderate social capital linking. As a result of this logic, our study indicated that social capital links may moderate the relationship between participation dimensions and social empowerment in UA. Additionally, the study further examines the indirect relationship (moderator effect) between participation and social empowerment that may exist as well. Based on the literature, the hypotheses formulated are as follows:

Hypothesis 4 (H4). Social capital linking moderates the relationship between participatory planning and social empowerment.

Hypothesis 5 (H5). Social capital linking moderates the relationship between participatory implementation and social empowerment.

Hypothesis 6 (H6). Social capital linking moderates the relationship between participatory evaluation and social empowerment.

Based on the literature and developed hypotheses, the conceptual framework for the study is given in Figure 3. 


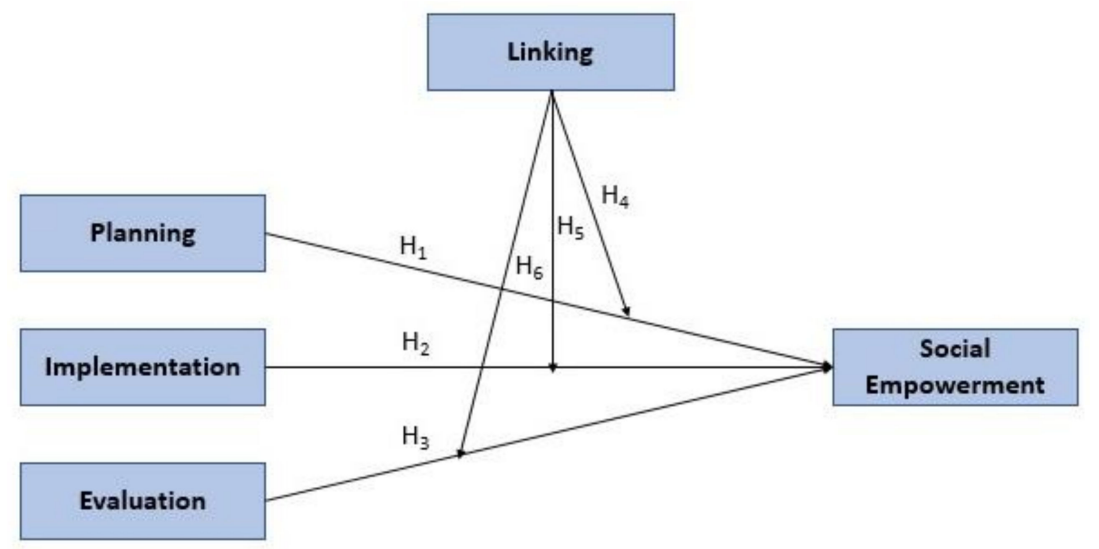

Figure 3. Conceptual framework.

\subsection{The Study Area}

The study was conducted in the Klang Valley area (Figure 4) due to its strategic location as the country's most developed urban region. It covers an area of approximately 2832 $\mathrm{km}^{2}$, and it is located roughly at the central part of the West Coast of Peninsular Malaysia, which is an urban agglomeration of 7.99 million people as of 2020 [44]. It is among the fastest growing metropolitan regions in Southeast Asia in both population and economic development. The area consists of Kuala Lumpur and Putrajaya with naturally delineated by hilly areas and the Port Klang coastline. Kuala Lumpur is the capital city and the largest city in Malaysia, covering an area of $243 \mathrm{~km}^{2}$ with an estimated population of 1.73 million as of 2019 [6]. Putrajaya, officially the Federal Territory of Malaysia, is a planned city that functions as the administrative capital and the judicial capital of Malaysia. Since the Klang Valley area is one of the densely populated urban areas in Malaysia, the researchers chose this region as the targeted research location for the current study. Moreover, the dataset for the study was taken from the respondents who were the participants of urban agriculture (UA) community programs authorized by the Department of Agriculture in the Klang Valley area.

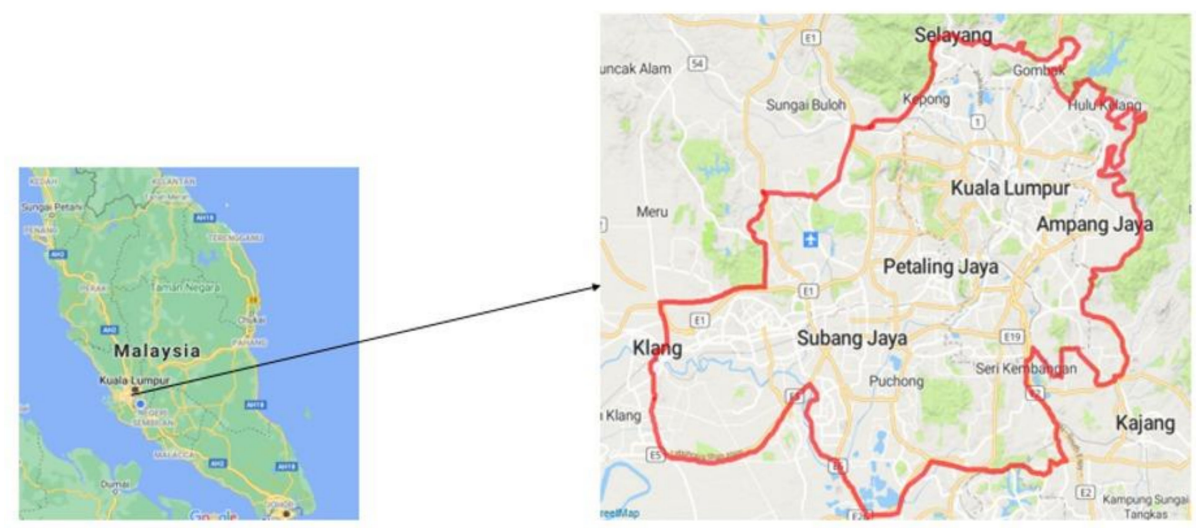

Figure 4. Location of the study. (left) Malaysia, (right) Klang Valley area.

\subsection{Measurements}

The self-administered questionnaire consisted of items on all three dimensions of participation: planning, implementation, and evaluation. The study adopted five items to measure planning (e.g., "participating in the process of designing the program to undertake by the members"), six items to measure implementation (e.g., "participating in the process of collaborating with community members to achieve community's objective"), and four items to measure evaluation (e.g., "participating in the process of evaluating the success of the program") as adopted from a study by Rilwanu (2014) [22]. Four items were adapted 
from Ibrahim (2016) to measure the link of social capital (e.g., "we received help and advice from agriculture extension officers") [45]. To measure economic empowerment, a six-item scale was adopted from Ndaeji (2014) and Rezai et al., (2014) (e.g., "I could reduce my financial problems by practicing UA") [46,47]. The 5-point Likert scale ranging from 1 (strongly disagree) to 5 (strongly agree) was used to measure all items in the questionnaire. Expert researchers were asked to examine the content validity of these items to ascertain whether the items were suitable to be used for the evaluation of UA program participants. Beforehand, a pilot study was carried out among Klang Perdana's UA community. Based on the results of both pilot test and expert examination, few changes were made to both the questionnaire's terminology and composition. An English version of the questionnaire was developed first, and later, it was translated into the Malay language.

\subsection{Data Collection}

This study selected the UA communities around the Klang Valley area as the study population. Data provided by the Department of Agriculture indicated that 2970 participants from seven districts across the Klang Valley area have been participated in the UA program since 2017. The districts are Dengkil, Seri Muda, Batu Caves, Kota Damansara, Templer, Batu Tiga, and Semenyih. Data collection took place from September 2018 to April 2019. Using G-Power analysis [48], 180 respondents were selected from these UA communities. Then, the researchers employed a multistage random sampling method to pick participants from all seven districts. After obtaining approval from the UA communities' leaders as well as setting the date and time for data collection, the researchers managed to distribute the prepared questionnaires to the targeted population. The time and date were set in advance before the data collection from selected areas to ensure the smoothness of the data collection. Data were collected using self-administered questionnaires, since it is more appropriate for respondents to be free to perform the task without intervention by researchers. The time required to complete the task is $20 \mathrm{~min}$, and the questionnaire was taken back after completion. To address the research objective, descriptive analysis and path analysis were carried out on the collected data. The demographics of the respondents were described using descriptive analysis, and both the approximation of model fit and evaluation of the proposed hypotheses were done with the help of PLS-SEM [49].

\subsection{Data Analysis}

The analysis in the paper used PLS-SEM to integrate the interdependencies between multiple variables. PLS-SEM is an alternative to co-variance-based SEM (CB-SEM), which defines its statistical properties. It is a multivariate technique that consists of two kinds of variables: namely, latent variables and manifest variables. The reasons for choosing this analysis approach are the application of an extension to existing theory [50] and a small sample size [51]. Hair et al., (2011) proposed PLS-SEM as an ideal tool to predict effects of the variables [52]. Hence, PLS-SEM is recommended by the researchers as the best approach to examine direct and indirect paths because of its inner and outer model analyses, which investigate the associations between latent constructs and manifest constructs. PLS-SEM's objective is to determine how well a proposed theoretical model is capable of estimating the covariance matrix for a sample dataset and its ability to clarify the variance in endogenous variables when investigating the model. Therefore, this approach was selected for the present study.

\section{Results}

\subsection{Profile of Respondents}

The majority of the respondents were in the age group of 41-60 years old (66.1\%), while the minority were between the ages 21 and 40 years old (10.6\%). The respondents ages ranged between 21 and 74 years old. The mean age is 53.63, showing that most of them are in the senior age range. This reflects the notion that elders are more likely to participate in the program, since most of them are retired and have a lot of time to engage 
with the community. Their expertise is often used, and they become role models for youth to be involved in project activities. According to Rilwanu (2015), elders tend to have more experience and knowledge, enabling them to have larger opportunities to exchange ideas and have close relationships with the community [22]. As for educational level, the results showed that $63.9 \%$ of respondents were secondary school/vocational leavers. On top of this, $30.0 \%$ of respondents held diplomas / degrees from colleges and universities, while the rest of the respondents $(6.1 \%)$ only had primary school education. For working sectors, $45.6 \%$ of respondents are in the 'others' category (self-employed or retired), 33.3\% are private workers, and only $21.1 \%$ of UA participants are government workers. Referring to years of participation, a majority of respondents $(53.9 \%)$ have participated for more than 1 year in the program, while the rest of them ( $46.1 \%$ ) have participated for less than 1 year (Table 1).

Table 1. Description of the sample.

\begin{tabular}{lcc}
\hline \multicolumn{1}{c}{ Variable } & Frequency & Percentage (\%) \\
\hline Age Group & 19 & \\
$21-40$ & 119 & $10.6 \%$ \\
$41-60$ & 42 & $66.1 \%$ \\
61 and above & & $23.3 \%$ \\
Average: 53.63 & 116 & \\
Gender & 64 & $64.4 \%$ \\
Male & 11 & $35.6 \%$ \\
Female & 169 & $6.1 \%$ \\
Marital Status & & $93.9 \%$ \\
Single & 11 & $6.1 \%$ \\
Married & 115 & $63.9 \%$ \\
Level of Education & 54 & $30.0 \%$ \\
Primary school & & \\
Secondary school/Vocational & 38 & $21.1 \%$ \\
College/University & 60 & $33.3 \%$ \\
Working Sector & 82 & $45.6 \%$ \\
Government & & $46.1 \%$ \\
Private & 83 & $53.9 \%$ \\
Others (self-employed or retired) & 97 & \\
Years of Participation & & \\
<1 year & & \\
$>1$ year & & \\
\hline
\end{tabular}

\subsection{Measurement Model}

The objective of the measurement model is to measure the reliability and validity of the items. In a reflective measurement model, three criteria need to be evaluated-internal consistency reliability, convergent validity, and discriminant validity. Both the Cronbach alpha (CA) and composite reliability (CR) were used to measure reliability. The CA and CR results for planning (PLAN) $(0.969,0.976)$, implementation (IMP) $(0.954,0.963)$, evaluation (EV) $(0.960,0.974)$, linking (LINK) $(0.933,0.949)$, and social empowerment (SE) $(0.958,0.968)$ are portrayed in Table 2. Both the CA and CR values recorded were in the acceptable range as the values are above 0.7, as suggested by Hair et al., (2011) [52]. Furthermore, to measure convergent validity, we obtained the items' AVE values. All AVE values were greater than the 0.5 threshold, as suggested by Henseler (2016) [53]. The AVE values were 0.889 for PLAN, 0.812 for IMP, 0.927 for EV, 0.789 for LINK, and 0.858 for SE. 
Table 2. Measurement model.

\begin{tabular}{|c|c|c|c|c|c|c|}
\hline Construct & Item Code & Loading & Outer Weight & CA & CR & AVE \\
\hline \multirow{5}{*}{ Planning (PLAN) } & PLAN1 & 0.956 & 0.226 & \multirow{6}{*}{0.969} & \multirow{6}{*}{0.976} & \multirow{6}{*}{0.889} \\
\hline & PLAN2 & 0.955 & 0.221 & & & \\
\hline & PLAN3 & 0.946 & 0.230 & & & \\
\hline & PLAN4 & 0.942 & 0.205 & & & \\
\hline & PLAN5 & 0.916 & 0.176 & & & \\
\hline \multirow{6}{*}{ Implementation (IMP) } & IMP1 & 0.865 & 0.173 & & & \\
\hline & IMP2 & 0.900 & 0.205 & \multirow{5}{*}{0.954} & \multirow{5}{*}{0.963} & \multirow{5}{*}{0.812} \\
\hline & IMP3 & 0.921 & 0.204 & & & \\
\hline & IMP4 & 0.921 & 0.179 & & & \\
\hline & IMP5 & 0.906 & 0.183 & & & \\
\hline & IMP6 & 0.981 & 0.166 & & & \\
\hline \multirow{3}{*}{ Evaluation (EV) } & EV1 & 0.953 & 0.343 & \multirow{4}{*}{0.960} & \multirow{3}{*}{0.974} & \multirow{3}{*}{0.927} \\
\hline & EV3 & 0.975 & 0.357 & & & \\
\hline & EV4 & 0.960 & 0.339 & & & \\
\hline \multirow{5}{*}{ Linking (LINK) } & LINK1 & 0.797 & 0.187 & & \multirow{5}{*}{0.949} & \multirow{5}{*}{0.789} \\
\hline & LINK2 & 0.879 & 0.215 & \multirow{4}{*}{0.933} & & \\
\hline & LINK3 & 0.908 & 0.250 & & & \\
\hline & LINK4 & 0.929 & 0.243 & & & \\
\hline & LINK5 & 0.923 & 0.227 & & & \\
\hline \multirow{5}{*}{ Social Empowerment (SE) } & SE2 & 0.933 & 0.218 & \multirow{5}{*}{0.958} & \multirow{5}{*}{0.968} & \multirow{5}{*}{0.858} \\
\hline & SE3 & 0.859 & 0.210 & & & \\
\hline & SE5 & 0.948 & 0.219 & & & \\
\hline & SE6 & 0.951 & 0.217 & & & \\
\hline & SE8 & 0.938 & 0.216 & & & \\
\hline
\end{tabular}

Note: Average variance extracted (AVE); Cronbach's alpha (CA); Composite reliability (CR).

The Fornell-Larcker and heterotrait-monotrait ratio (HTMT) were the measurements used to assess discriminant validity [54]. As shown in Table 3, the Fornell and Larcker's Test indicated values that are greater than the correlations among variables. Meanwhile, the HTMT results in Table 4 are lower than the 0.09 threshold [55]. These values point to the conclusion that the discriminant validity of the reflective measurement model was achieved.

Table 3. Fornell-Larcker criterion.

\begin{tabular}{lccccc}
\hline & EV & IMP & LINK & PLAN & SE \\
\hline EV & $\mathbf{0 . 9 6 3}$ & & & & \\
IMP & 0.817 & $\mathbf{0 . 9 0 1}$ & & & \\
LINK & 0.449 & 0.586 & $\mathbf{0 . 8 8 8}$ & & \\
PLAN & 0.864 & 0.836 & 0.408 & $\mathbf{0 . 9 4 3}$ & \\
SE & 0.616 & 0.788 & 0.740 & 0.638 & $\mathbf{0 . 9 2 6}$ \\
\hline
\end{tabular}

Note: Evaluation (EV); implementation (IMP); linking (LINK); planning (PLAN); social empowerment (SE).

Table 4. HTMT (heterotrait-monotrait ratio).

\begin{tabular}{lcccc}
\hline & EV & IMP & LINK & PLAN \\
\hline IMP & $\mathbf{0 . 8 5 5}$ & & & \\
LINK & 0.475 & $\mathbf{0 . 6 1 9}$ & & \\
PLAN & 0.896 & 0.872 & $\mathbf{0 . 4 2 2}$ & \\
SE & 0.642 & 0.819 & 0.779 & $\mathbf{0 . 6 5 7}$ \\
\hline
\end{tabular}

Note: Evaluation (EV); implementation (IMP); linking (LINK); planning (PLAN); social empowerment (SE).

\subsection{Assessment of Structural Model}

The structural model assessment was conducted once the measurement model was completed and all requirements were satisfied. The structural model characterizes the underlying concept of the path model. Structural model evaluation allows the researchers 
to determine how well the empirical data support the concepts covered in the theoretical framework. The objective of the structural model is to test the independent associations among the constructs suggested in the research model. The key criteria for evaluating the structural model in PLS-SEM is assessing for collinearity issues (Step 1), significance of the path coefficients (Step 2), level of $\mathrm{R}^{2}$ value (Step 3), $\mathrm{f}^{2}$ effect size (Step 4), and predictive relevance $\left(Q^{2}\right)$ (Step 5). In this study, 5000 bootstraps were used to assess the structural model. The VIF values of all constructs in the structural model are given in the Table 5. It was observed that there is no collinearity issue present in the model, as all the VIF values ranged from 1.582 to 5.090, which are below the threshold of $<10$, as suggested by Aiken et al., (1991) [56].

Table 5. Variance inflation factors (VIF) for all constructs.

\begin{tabular}{lcc}
\hline & Construct & VIF \\
\hline PLAN & 5.090 \\
IMP & 4.739 \\
EV & 4.470 \\
LINK & 1.582 \\
\hline
\end{tabular}

Table 6 shows the significance of the path coefficient for all constructs in the current study. The results revealed that implementation (IMP) contributes to social empowerment (SE) positively $(\beta=0.407, p<0.05)(\mathrm{H} 2)$. Surprisingly, the moderating effect of IMP*LINK on social empowerment (SE) was negative and significant ( $\beta=-0.231, p<0.05)$ (H5). However, the findings showed that $\mathrm{H} 1, \mathrm{H} 3, \mathrm{H} 4$, and $\mathrm{H} 6$ do not have a significant effect on social empowerment (SE) with $\beta=0.115, p>0.05 ; \beta=-0.084, p>0.05 ; \beta=-0.037$, $p>0.05$; and $\beta=0.026, p>0.05$ respectively. Thus, we rejected the hypotheses of $\mathrm{H} 1, \mathrm{H} 3$, $\mathrm{H} 4$, and H6. The results also show that the $\mathrm{R}^{2}$ value for social empowerment (SE) is 0.784 , suggesting that $78.4 \%$ of the variance in social empowerment (SE) was explained by PLAN, IMP, EV, and LINK.

Table 6. Hypotheses' testing results.

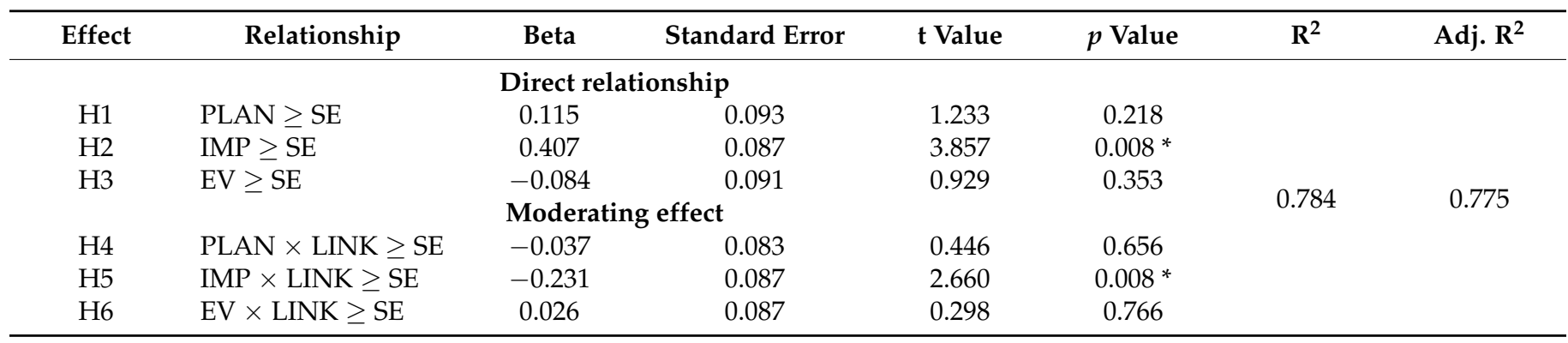

Note: ${ }^{*} p<0.01$, planning (PLAN); implementation (IMP); evaluation (EV); linking (LINK); social empowerment (SE).

Table 7 shows the effect sizes of the respective variables. According to Cohen and Uphoff (1977), the guidelines for evaluating $\mathrm{f}^{2}$ are the values of $0.02,0.15$, and 0.35 representing small, medium, and large effect sizes, respectively [57]. The results in Table 7 revealed that implementation (IMP) has a small effect on social empowerment (SE), as the $\mathrm{f}^{2}$ was recorded at 0.067 , which is between 0.02 and 0.15 . The interaction term implementation (IMP) $x$ linking (LINK) also has a small effect on social empowerment (SE), with a $0.067 \mathrm{f}^{2}$ recorded, which is between 0.02 and 0.15 . Meanwhile, planning (PLAN), evaluation (EV), planning * linking (PLANxLINK), and evaluation * linking (EVAxLINK) have $\mathrm{f}^{2}$ values that are less than 0.02 on social empowerment (SE), which is equivalent to no effect. The $Q^{2}$ of social empowerment (SE) is 0.648 , which signifies that the research model has a good predictive relevance, with $Q^{2}$ values larger than zero $\geq$. 
Table 7. Effect sizes of the variables.

\begin{tabular}{cccc}
\hline Effect & Relationship & $\mathbf{f}^{\mathbf{2}}$ & $\mathbf{Q}^{\mathbf{2}}$ \\
\hline \multicolumn{3}{c}{ Direct relationship } \\
H1 & PLAN $\geq$ SE & 0.012 \\
H3 & IMP $\geq$ SE $\geq$ SE & 0.067 & 0.648 \\
Moderating effect & 0.006 \\
H5 & PLAN $\times$ LINK $\geq$ SE & 0.002 \\
H6 & IMP $\times$ LINK $\geq$ SE & 0.067 & \\
\hline
\end{tabular}

Figure 5 shows the results of the structural model with the interaction term of linking social capital in the relationship between participatory dimensions (planning, implementation, and evaluation) toward social empowerment. Referring to the figure below, it is clearly indicated that linking social capital moderates the relationship between participatory planning and social empowerment.

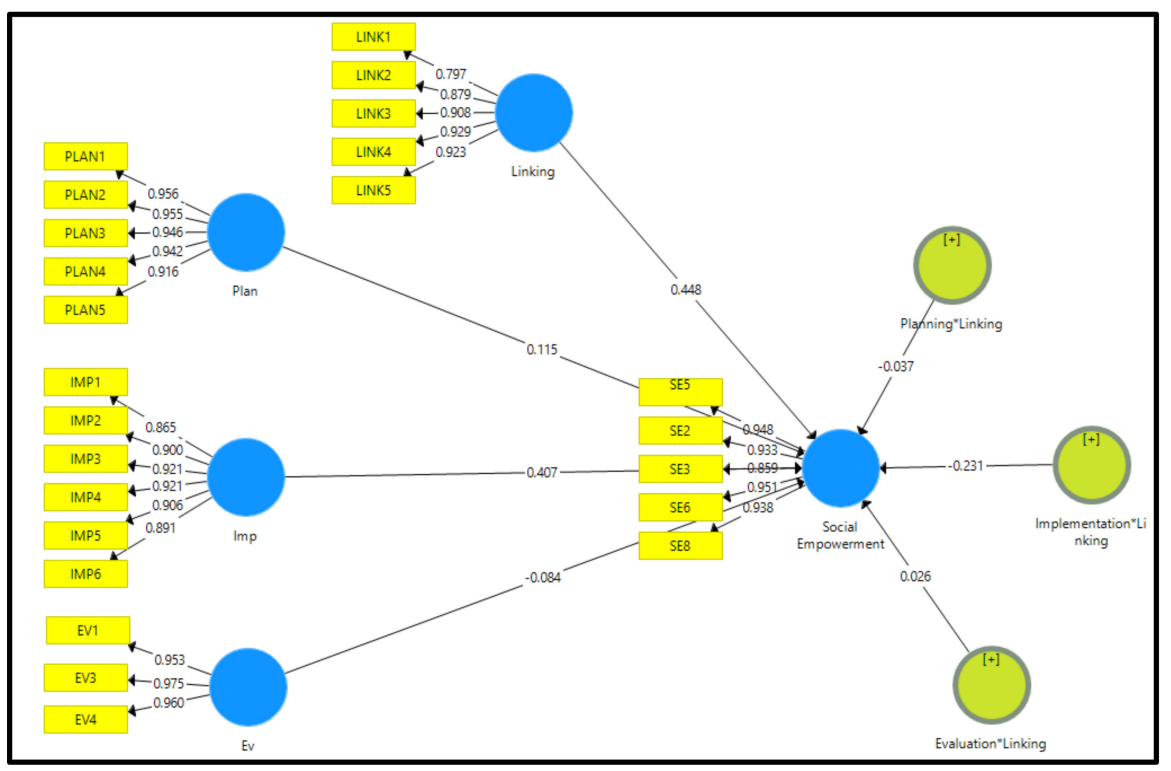

Figure 5. Results of the structural model with planning (PLAN), implementation (IMP), evaluation (EV), linking (LINK), and social empowerment (SE) constructs.

Figures 6-8 show examples of importance-performance matrix analysis (IPMA) findings in developing the social empowerment of communities. The result showed that implementation is the variable that records the highest importance in this study. This suggests that participation in implementation is a variable that needs to be emphasized, as it has the potential to increase community social empowerment. 


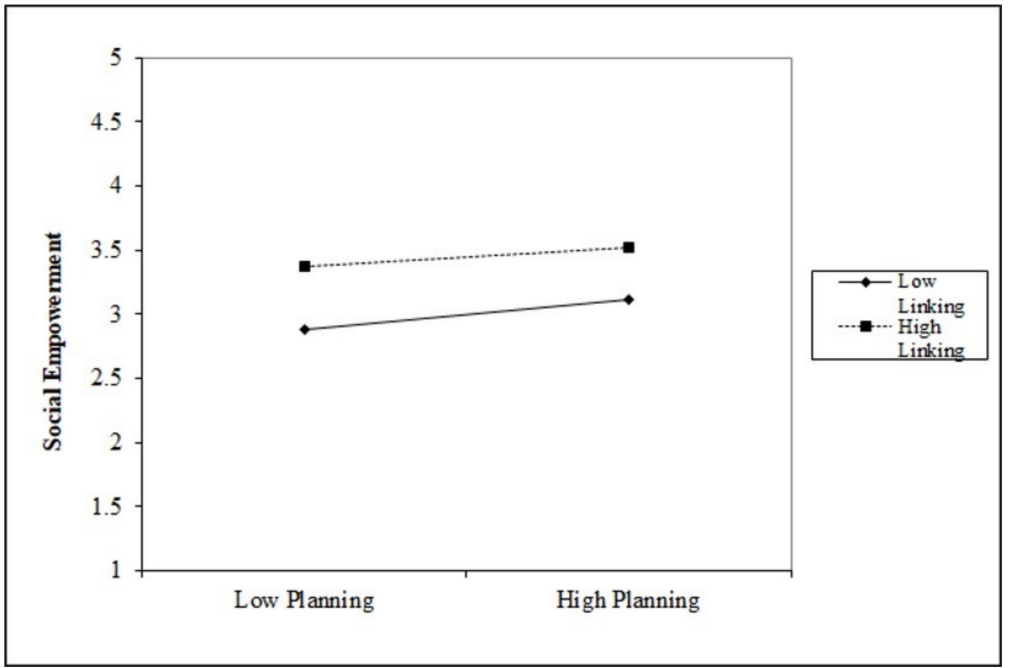

Figure 6. Importance-performance matrix analysis (IPMA) for participatory planning.

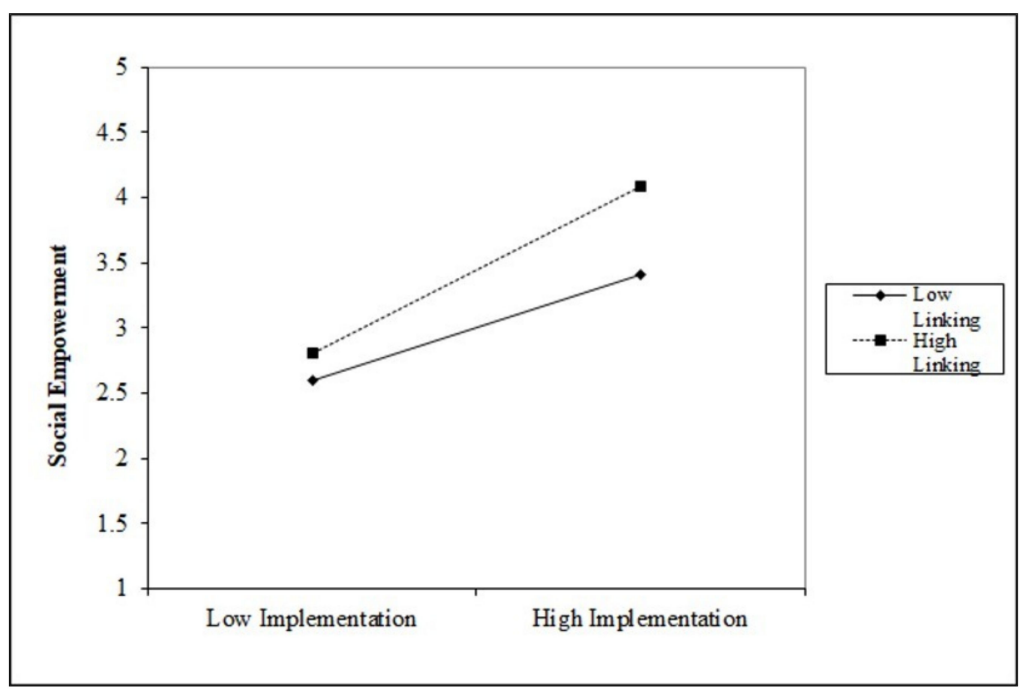

Figure 7. IPMA for participatory implementation.

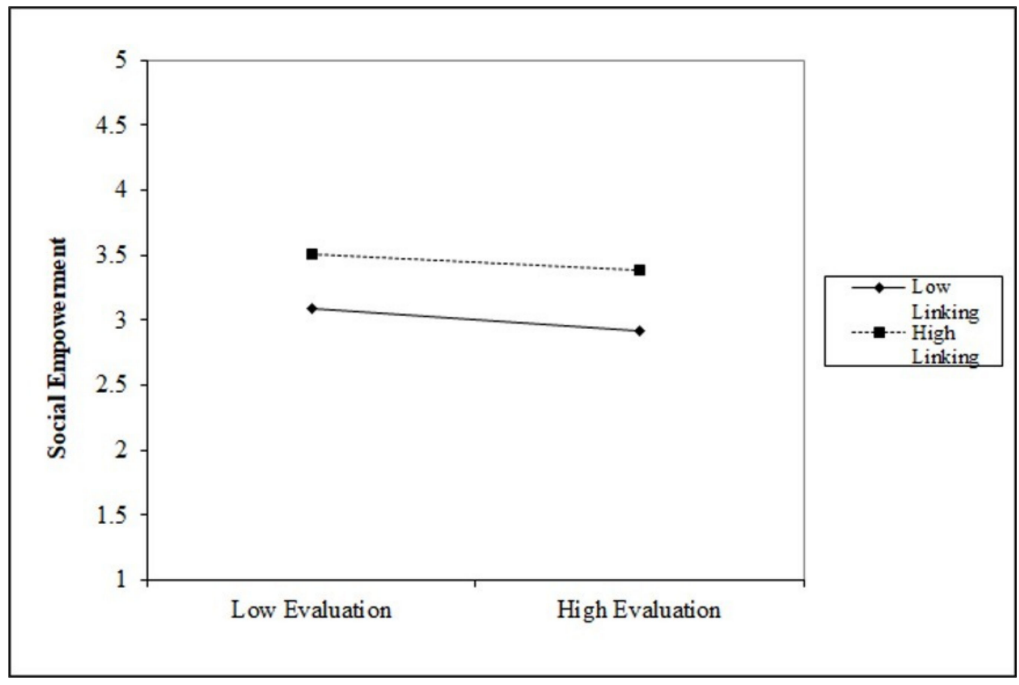

Figure 8. IPMA for participatory evaluation. 


\section{Discussion}

The objective of this study is to explore the direct and indirect effects of predictors on social empowerment. The results generated show no significant relationship between planning and evaluation toward the social empowerment of UA program's participants. This finding is not surprising, as it is in line with past studies done by Cyril et al., (2015) and Wahdy et al., (2017), which claimed that there is a lack of public involvement at the planning stage in many activities $[58,59]$. A majority of the programs are implemented using the 'top-down' approach as opposed to the 'bottom-up' participatory methods, thus limiting their impact and reducing participation in planning by the community. Additionally, they underlined that when community leaders plan activities, they rarely involve as community members. Basically, only two to three persons are involved at the beginning of an activity [58]. On the other hand, Cohen and Uphoff (1977) claimed that the evaluation process of community development projects is sometimes totally missing, and communities severely lack the tools of evaluation due to low literacy rates [57]. Hence, this study managed to fill the gaps by showing that the planning and evaluation processes are not robust enough to empower UA communities. It also denotes that high planning and implementation is required among communities to ensure that the repercussion of UA is adequate to encourage empowerment among urban societies.

In this research, we also discovered that participation in program implementation influences social empowerment. Local governments (town planners) of urban areas need to consider several locations as potential spaces for urban dwellers, whether for housing areas that have already been developed or will be developed in the future. This deliberation is intended for the community to have areas to establish, improve, or expand UA activities. Substantially, coordination and cooperation between agencies and the establishment of a platform to promote all parties' involvement in the implementation stage are required. These acts can foster awareness and interest in the importance of agriculture as a direct contributor to the well-being of urban communities $[27,34,60]$. To ascertain the sustainment of urban community's participation, the private sector and hypermarkets can also develop initiatives that promote the purchase of planting tools, seeds, and fertilizers at affordable prices, hence increasing demand for agriculture crops. On the other hand, non-governmental organizations (NGOs) can use media platforms to provide simple technological manuals or organize weekend mini-courses on agriculture to provide hands-on activities that can generate interest amongst communities.

Furthermore, UA should be prioritized as a way to contain urban dwellers' rising poverty rate through the lowering of family expenditures. It was unnoticed that the Malaysian government has provided a hefty budget for UA communities in certain areas to develop and operate UA programs/activities. Nonetheless, apart from start-up funds, technical support should also be offered for the cultivation of crops in low-cost residential flats with limited space in order to ensure a supply of fresh produce for residents. Although UA practices are not new in Malaysia, their implementation is still scarce; hence, thorough assistance and prolonged cooperation either from government bodies, private agencies, or NGOs are much coveted. This is associated with this study's findings, which signified the importance of linking social capital to the implementation process. The significant advantage of such efforts is that they have the ability to reshape urban populations when undertaken collectively [60].

Through planning, implementation, and assessment, UA has the ability to achieve the social empowerment goals of managing sustainable slums and managing urbanization as part of urban settlement planning. Although there is no clear link between urban agriculture and urban poverty, social empowerment through UA can help alleviate poverty and meet urban food demands, as urban agriculture can inspire small businesses to sell vegetables and compost [61]. As a result of the technology used, such as horticulture, hydropower, rooftop, and aquaponics, UA does not require a significant area of land, and it can be replicated without a large area of land. As a result, it may serve as the household's primary source of food, and it plays an important role in reducing the food 
insecurity. Urban agriculture improves the economic situations as well as the health of poor and vulnerable families, particularly women and children, despite the fact that it is still widely regarded as a transient or peripheral activity that does not lead to long-term urban development. Furthermore, UA integrates agricultural and urban development challenges. It has a direct and indirect impact on the citizens' quality of life in numerous ways. Agriculture in urban areas is generally regarded as a resource that contributes to food security for families and communities as well as the improvement of living conditions in poor neighbourhoods in both developing and developed countries, so it would be a good program to increase the social empowerment of the people in Klang Valley, Malaysia.

Further, UA has the ability to contribute to the development of substantial capacities for planning, project implementation, and collective action at the neighborhood level. To do local development work, the UA program relies on solid community organizations with strong planning and implementation capacities. With effective and stable support from stakeholders, implementation of the program could educate the community on UA initiatives and how they can be improved. When government actions are integrated with community needs, strong social cohesion among the community could evolve, therefore creating an agriculture knowledgeable society. Eventually, dependency on third parties is no longer required as people can manage the crops on their own. In other words, the initiatives that were first pioneered by stakeholders are promptly handled by the participants themselves. Hence, through this process, the community will become selfreliant and more empowered.

\section{Conclusions}

The research has indicated the important role of participation in the planning, implementation, and evaluation stages in order to ensure the success of UA programs. Although there is less surface area of agricultural land available in the city, and it would be difficult to feed the entire population of a city such as the Klang Valley area, Malaysia with the available land, a multi-approach implementation of gardening in urban environments, such as land agriculture, container gardening on balconies and roofs, and a vertical integration of elements would certainly contribute to the social empowerment of disadvantaged neighborhoods. Moreover, the role of agencies, NGOs, and communities in building strong linkages is crucial to the enhancement of social empowerment among UA program participants in the study area. As a program at the community level, UA can be a platform for participation in many communities, especially those in low-income urban areas, as the effort also works as an alternative to managing household expenses in terms of fresh produce for daily needs. Therefore, the success of UA programs initiated by the Department of Agriculture requires not only the community's effort but also the support of related agencies and other organizations linked through social capital in order to ensure the program's sustainability.

Moreover, UA is a way to enhance food security and offer environmental health and social benefits. At the same time, the availability of fresh, home-grown food products, in particular fruits and vegetables through UA, advances the nutritional status of household members and thereby improves health. Direct access to food often allows particularly poor households to consume a more diverse diet than they would otherwise be able to afford. In his study, Maxwell (1998) connected the aspect of maternal care to UA, arguing that mothers engaged in UA, as opposed to other forms of non-farm employment away from home, have an increased ability to care for their children [62]. This was in return believed to positively impact levels of child nutrition and their food security. Further, UA is assumed to create an "opportunity cost" - domestic producers can either save income, via the consumption of home-produced foodstuffs that are cheaper to produce than to buy from the market, and/or increase income by selling or trading their products. Hence, higher cash income at the household level is positively linked to food security as households are believed to have greater access to food products both in terms of quantity and quality.

The outcomes of this study are restricted to the Malaysian respondents who were the participants of UA community programs authorized by the Department of Agriculture in 
the Klang Valley area. Due to potential inequalities in people's attitudes and behaviors, a sample covering diverse populations could produce different results, and further investigations should be undertaken with different contexts and nations in order to reduce location feedbacks. The sample size of this study was 180 respondents, and the large sample size would be ideal to increase the validity of the results. Furthermore, the authors cannot make any casual claims or evaluate the links between the investigated antecedents and social empowerment over time due to the cross-sectional nature of this study. Research designs that allow for causal inference are required to conduct a true causal examination of the impact of individual social empowerment over time with a longitudinal design. Moreover, future research should build on this work by developing and testing integrated comprehensive models with the goal of capturing a more holistic knowledge of the underlying causes of social empowerment.

Author Contributions: Conceptualization, N.S.N. and S.S.A.S.; methodology, N.S.N.; software, N.S.N.; validation, N.A., M.R.R. and J.S.; formal analysis, N.S.N.; investigation, N.S.N.; resources, N.S.N.; data curation, N.S.N.; writing-original draft preparation, N.S.N. and S.S.A.S.; writingreview and editing, N.A., M.R.R., J.S., N.S.N., S.S.A.S. and R.W.; visualization, N.S.N. and S.S.A.S.; supervision, M.R.R., N.A. and J.S.; project administration, M.R.R., N.A., R.W. and J.S. All authors have read and agreed to the published version of the manuscript.

Funding: This research received no external funding.

Institutional Review Board Statement: Not applicable.

Informed Consent Statement: Informed consent was obtained from all subjects involved in the study.

Data Availability Statement: Not applicable.

Conflicts of Interest: The authors declare no conflict of interest.

\section{References}

1. Duflot, L. Urbanization Policy in Malaysia and Its Impacts. Graphite Publications. 2012. Available online: http: / / graphitepublications.com/urbanization-policy-in-Malaysia-and-its-impacts/ (accessed on 23 May 2021).

2. FAO. The Impact of Global Change and Urbanization on Household Food Security, Nutrition, and Food Safety. 2020. Available online: https:/ / www.fao.org/ag/agn/nutrition/national_urbanization_en.stm (accessed on 23 June 2021).

3. United Nations. Resolution Adopted by the General Assembly on 6 July 2017, Work of the Statistical Commission Pertaining to the 2030 Agenda for Sustainable Development. 2017. Available online: https://ggim.un.org/documents/a_res_71_313.pdf (accessed on 28 November 2020).

4. World Urbanization Prospects. Population Division. 2020. Available online: https://population.un.org/wpp/Publications/ (accessed on 27 December 2020).

5. Department of Economic and Social Affairs (DESA). Population, Food Security, Nutrition and Sustainable Development. 2021. Available online: https://www.un.org/development/desa/pd/sites/www.un.org.development.desa.pd/files/undesa_pd_20 21_policy_brief.pdf (accessed on 2 August 2021).

6. Department of Statistics Malaysia (DOSM). Malaysia Household Income and Basic Amenities Survey Report. 2019. Available online: https:/ / www.dosm.gov.my/v1/index.php?r=column/cthemeByCat\&cat=120\&bul_id=TU00TmRhQ1N5TUxHVWN0 T2VjbXJYZz09\&menu_id=amVoWU54UT10a21NWmdhMjFMMWcyZz09 (accessed on 10 August 2021).

7. Ahmed, F.; Siwar, C.; Bashawir, A.; Mia, S. Urbanization and Urban Poverty in Malaysia: Consequences and Vulnerability. J. Appl. Sci. 2016, 16, 154-160. [CrossRef]

8. Lin, B.; Philpott, S.; Jha, S. The future of urban agriculture and biodiversity-ecosystem services: Challenges and next steps. Basic Appl. Ecol. 2015, 16, 189-201. [CrossRef]

9. FAO; USAI. The State of Food Security and Nutrition in the World 2017. Building Resilience for Peace and Food Security. 2017. Available online: http:/ / www.fao.org/3/a-I7695e.pdf (accessed on 5 March 2019).

10. Badami, M.G.; Ramankutty, N. Urban agriculture and food security: A critique based on an assessment of urban land constraints. Glob. Food Secur. 2015, 4, 8-15. [CrossRef]

11. Mogk, J.E.; Sarah, W.; Mary, J.W. Promoting urban agriculture as an alternative land use for vacant properties in the city of Detroit: Benefits, problems and proposals for a regulatory framework for successful land use integration. Wayne L. Rev. 2010, $56,1521$.

12. Liorach-Massana, P.; Farreny, R.; Oliver-Solà, J. Are cradle to cradle certified products environmentally prefer-able? Analysis from an LCA approach. J. Clean. Prod. 2015, 93, 243-250. [CrossRef]

13. Drescher, A.W.; Isendahl, C.; Cruz, M.C.; Karg, H.; Menakanit, A. Urban and Peri-Urban Agriculture in the Global South. In Urban Ecology in the Global South; Springer: Cham, Switzerland, 2021; pp. 293-324. 
14. FAO. Moving forward on Food Loss and Waste Reduction. The State of Food and Agriculture. 2019. Available online: https:/ / www.fao.org/policy-support/tools-and-publications/resources-details/en/c/1242090/ (accessed on 23 September 2021).

15. National Agrofood Policy (NAFP). Malaysia's Agrofood Policy (NAP 2011-2020). Available online: https://ap.fftc.org.tw / article/1368 (accessed on 20 September 2021).

16. Department of Agriculture. Program Pertanian Bandar. 2019. Available online: http://www.doa.gov.my/index.php/pages/ view/332 (accessed on 26 October 2021).

17. United Nation Development Program. What are the Sustainable Development Goals? Available online: https://www.undp.org/ sustainable-development-goals\#sustainable-cities-and-communities (accessed on 11 July 2021).

18. Yusoff, N.H.; Hussain, M.R.M.; Tukiman, I. Roles of community towards urban farming activities. Plan. Malays. 2017, 15, 271-278.

19. The Star. Urban Farms Grow out of Community Gardens. 2014. Available online: http://www.thestar.com.my/news/ community/2014/05/06/urban-farms-grow-out-of-community-gardensputrajaya-corp-embarks-on-pilot-project-andprovides-techn/ (accessed on 29 May 2021).

20. Ramalingam, L.; Sharifuddin, J.; Mohamed, Z.A.; Ali, F. Community garden programme: The volunteers' satisfaction. Int. J. Acad. 2018, 8, 436-443. [CrossRef]

21. Babaei, H.; Ahmad, N.; Gill, S.S. Bonding, bridging and linking social capital and empowerment among squatter settlements in Tehran, Iran. World Appl. Sci. J. 2012, 17, 119-126.

22. Rilwanu, A. Participation, Social Capital and Empowerment among Members of Kankara Local Community Fadama User Groups in Katsina State, Nigeria. Ph.D. Thesis, Universiti Putra Malaysia, Serdang, Malaysia, 2014.

23. Silverman, R. Caught in the Middle: Community Development Corporations (CDCs) and the Conflict between Grassroots and Instrumental Forms of Citizen Participation. Community Dev. 2005, 36, 35-51. [CrossRef]

24. Samah, A.A.; Aref, F. People's participation in community development: A case study in a planned village settlement in Malaysia. World Rural Obs. 2009, 1, 45-54.

25. Mohapatra, S.; Bimal, K.S. Determinants of participation in self-help-groups (SHG) and its impact on women empowerment. IGDR 2016, 9, 53-78. [CrossRef]

26. Omar, D.; Omar, K.A.; Othman, S.; Yusoff, Z.M. Youth Participation in Urban Neighbourhood Community. Procedia Soc. Behav. Sci. 2016, 234, 309-316. [CrossRef]

27. Haldane, V.; Chuah, F.L.; Srivastava, A.; Singh, S.R.; Koh, G.C.; Seng, C.K.; Legido-Quigley, H. Community participation in health services development, implementation, and evaluation: A systematic review of empowerment, health, community, and process outcomes. PLoS ONE 2019, 14, e0216112. [CrossRef]

28. Gill, S.; Nathans, L.L.; Seidel, A.J.; Greenberg, M.T. Early head start-up planning: Implications for staff support, job satisfaction, burnout, and turnover. J. Community Psychol. 2017, 45, 443-458. [CrossRef]

29. Nichols, L. Participatory program planning: Including program participants and evaluators. Eval. Program Plan. 2002, 25, 1-14. [CrossRef]

30. Forsyth, A. International Content in the Journal of the American Planning Association. J. Am. Plan. Assoc. 2020, 87, 1-2. [CrossRef]

31. Thibert, J. Making Local Planning Work for Urban Agriculture in the North American Context. J. Plan. Educ. Res. 2012, 32, 349-357. [CrossRef]

32. Horst, M.; McClintock, N.; Hoey, L. The Intersection of Planning, Urban Agriculture, and Food Justice: A Review of the Literature. J. Am. Plan. Assoc. 2017, 83, 277-295. [CrossRef]

33. Rossi, P.H.; Lipsey, M.W.; Freeman, H.E. Evaluation: A Systematic Approach, 7th ed.; Sage: Irvine, CA, USA, 2004.

34. Gagnon, R.J.; Franz, N.K.; Garst, B.A.; Bumpus, M.F. Factors impacting program delivery: The importance of implementation research in extension. J. Hum. Sci. Ext. 2015, 3, 68.

35. Hoe, K.C.; Wahab, A.H.; Bakar, S.H.A.; Islam, M.R. Community participation for rural poverty alleviation: A case of the Iban community in Malaysia. Int. Soc. Work 2017, 6, 518-536. [CrossRef]

36. Prasetyo, A.S.; Aulia, A.N.; Sinaga, A.S. Performance of Agricultural Extension Workers in Implementing Urban Agriculture Programs in Banyumanik District, Semarang City, Indonesia. J. Socioecon. Dev. 2020, 3, 29-36. [CrossRef]

37. Weaver, L.; Cousins, J.B. Unpacking the participatory process. J Multidiscip. Eval. 2004, 1, 19-40.

38. Akhter, J.; Cheng, K. Sustainable empowerment initiatives among rural women through microcredit borrowings in Bangladesh. Sustainability 2020, 12, 2275. [CrossRef]

39. Yan, X.; Lin, H.; Clarke, A. Cross-Sector Social Partnerships for Social Change: The Roles of Non-Governmental Organizations. Sustainability 2018, 10, 558. [CrossRef]

40. Claridge, T. Functions of social capital-bonding, bridging, linking. Soc. Cap. Res. 2018, 20, 1-7.

41. Szreter, S.; Woolcock, M. Health by association? Social capital, social theory, and the political economy of public health. Int. J. Epidemiol. 2004, 33, 650-667. [CrossRef]

42. Woolcock, M. Social capital in theory and practice: Where do we stand. Soc. Cap. Econ. Dev. Well Being Dev. Ctries. 2002, 1, 18-39.

43. Bakker, Y.W.; de Koning, J.; van Tatenhove, J. Resilience and social capital: The engagement of fisheries communities in marine spatial planning. Mar. Policy 2019, 99, 132-139. [CrossRef] 
44. Department of Statistics Malaysia (DOSM). Population \& Demography. 2020. Available online: https://www.dosm.gov.my/ v1/index.php?r=column/ctwoByCat\&parent_id=115\&menu_id=L0pheU43NWJwRWVSZklWdzQ4TlhUUT09 (accessed on 22 September 2021).

45. Ibrahim, M.B. Role of Participation in Decision Making and Social Capital on Sustainability of Watershed Usage among Peri-urban Agricultural Farmers of Kwadon, Gombe State, Nigeria. Ph.D. Thesis, Universiti Putra Malaysia, Serdang, Malaysia, 2016.

46. Ndaeji, M.N. Participation in Self-Help Groups and Empowerment among Rural Women in Niger State, Nigeria. Ph.D. Thesis, Universiti Putra Malaysia, Serdang, Malaysia, 2014.

47. Shamsudin, M.N.; Rezai, G.; Teng, P.K. Public Attitude toward Urban Agriculture in Malaysia: Study on Values and Knowledge in Klang Valley. J. Food Prod. Mark. 2014, 20, 35-48. [CrossRef]

48. Faul, F.; Erdfelder, E.; Lang, A.G.; Buchner, A.G. Power 3: A flexible statistical power analysis program for the social, behavioral, and biomedical sciences. Behav. Res. Methods 2007, 39, 175-191. [CrossRef] [PubMed]

49. Hair, J.F.; Sarstedt, M.; Ringle, C.M.; Gudergan, S.P. Advanced Issues in Partial Least Squares Structural Equation Modeling; Sage: Irvine, CA, USA, 2017.

50. Hair, J.F.; Ringle, C.M.; Sarstedt, M. Partial least squares structural equation modelling: Rigorous applications, better results and higher acceptance. LRP 2013, 46, 1-12.

51. Sarstedt, M.; Ringle, C.M.; Henseler, J.; Hair, J.F. On the Emancipation of PLS-SEM: A Commentary on Rigdon (2012). Long Range Plan. 2014, 47, 154-160. [CrossRef]

52. Hair, J.F.; Ringle, C.M.; Sarstedt, M. PLS-SEM: Indeed, a silver bullet. J. Mark. Theory Pract. 2011, 19, 139-152. [CrossRef]

53. Henseler, J.; Hubona, G.; Ray, P.A. Using PLS path modeling in new technology research: Updated guidelines. Ind. Manag. Data Syst. 2016, 116, 2-20. [CrossRef]

54. Fornell, C.; Larcker, D.F. Structural equation models with unobservable variables and measurement error: Algebra and statistics. J. Mark Res. 1981, 18, 382-388. [CrossRef]

55. Gold, A.H.; Malhotra, A.; Segars, A.H. Knowledge Management: An Organizational Capabilities Perspective. J. Manag. Inf. Syst 2001, 18, 185-214. [CrossRef]

56. Aiken, L.S.; West, S.G.; Reno, R.R. Multiple Regression: Testing and Interpreting Interactions; Sage: Irvine, CA, USA, 1991.

57. Cohen, J.M.; Uphoff, N.T. Rural Development Participation: Concepts and Measures for Project Design, Implementation and Evaluation; Rural Development Committee, Center for International Studies, Cornell University: Ithaca, NY, USA, 1977.

58. Cyril, S.; Smith, B.J.; Possamai-Inesedy, A.; Renzaho, A.M. Exploring the role of community engagement in im-proving the health of disadvantaged populations: A systematic review. Glob. Health Action. 2015, 8, 29842. [CrossRef]

59. Wahdy, A.A.; Maksum, I.R.; Darmajanti, L. The challenges of enhancing participation in urban community empowerment (The Case of Community Empowerment Program for Villages (PPMK) Implementation in 4 Villages in Jakarta. JKAP 2017, 21, 107-125.

60. Fagotto, E.; Fung, A. Empowered participation in urban governance: The Minneapolis neighbourhood revitalization program. Int. J. Urban Reg. Res. 2006, 30, 638-655. [CrossRef]

61. Edwards, F.; Aknolt, P.; Pakpahan, K. Urban Agriculture as a Solution to the Problem of Urbanization in the City of Bandung; Australian Consortium for In-Country Indonesian Studies (ACICIS); Universitas Katolik Parahyangan: Bandung, Indonesia, $2014 ;$; pp. 1-45.

62. Maxwell, D.; Levin, C.; Csete, J. Does urban agriculture help prevent malnutrition? Evidence from Kampala. Food Policy 1998, 23, 411-424. [CrossRef] 